\title{
Perancangan Akuarium dengan Biomorphic Form \& Patterns
}

\author{
I Dewa Bagus Andi Kurniata dan Johanes Krisdianto \\ Departemen Arsitektur, Fakultas Arsitektur Desain dan Perencanaan, Institut Teknologi Sepuluh Nopember (ITS) \\ e-mail: john_kris@arch.its.ac.id
}

\begin{abstract}
Abstrak-Menurunnya populasi ikan khususnya tuna di Indonesia terjadi karena adanya illegal fishing dan eksploitasi berlebih. Ikan ditangkap tanpa melihat usia dari ikan tersebut. Hal ini menyebabkan ikan yang tertangkap belum memasuki masa reproduksi sehingga berdampak pada jumlah ikan yang ada dilautan. Selain itu penangkapan tanpa melihat usia ikan juga dapat menurunkan kualitas dari ikan yang ditangkap sehingga banyak ikan yang terbuang sia-sia. Arsitektur dapat membantu menyelesaikan masalah menurunnya populasi ikan dengan menciptakan sebuah wadah yang mampu menekan berkurangnya sumber pangan ini. Salah satu fasilitas tersebut adalah akuarium air laut. Dengan mempertimbangkan dampak ekologi akuarium ini tidak hanya digunakan sebagai konservasi biota laut, namun juga diharapkan mampu menjadi sarana edukasi budidaya bagi masyarakat. Untuk membuat objek rancang lebih menarik dan sesuai dengan konteks rancangnya maka dalam perancangannya dapat dilakukan penerapan Biomorphic Form \& Patterns yang merupakan bagian dari Biophilic Design.
\end{abstract}

Kata Kunci-Akuarium, Biomorphic Form \& Patterns, Biophilic Design, Ekologi, Populasi Ikan.

\section{PENDAHULUAN}

KAN merupakan salah satu sumber pangan utama bagi manusia, kandungan proteinnya yang tinggi menjadikan ikan dicari sebagai sumber protein. Berdasarkan World Wildlife Fund (WWF) meningkatnya permintaan manusia terhadap ikan dan banyaknya jumlah kapal penangkap ikan yang beroperasi menyebabkan jumlah tangkapan ikan semakin sedikit. Ini artinya jumlah ikan dilautan saat ini telah diexploitasi secara besar-besaran. WWF memperkirakan $2 / 3$ populasi ikan didunia telah diambil secara berlebih ataupun berada pada batas ikan mampu untuk bereproduksi [1].

Masalah exploitasi ikan ini terjadi di seluruh dunia. Masalah ini terjadi tanpa kita sadari dan tentu akan mengancam ketersediaan pangan dunia. Populasi dari ikan yang digunakan sebagai pangan sejak tahun 1970 telah berkurang lebih dari $50 \%$. Hal ini tentu harus diatasi untuk mencegah punahnya populasi ikan dunia [2].

Di Indonesia masalah mengenai turunnya jumlah ikan juga menjadi isu yang dibahas sudah cukup lama. Populasi ikan yang berkurang disebabkan oleh tingginya permintaan terhadap ikan dengan nilai konsumsi tinggi seperti ikan tuna, tongkol, dan cakalang. Hal ini dikhawatirkan dapat mengancam keberlangsungan ekosistem laut dan mengancam ketersediaan ikan sebagai salah satu sumber pangan nasional.

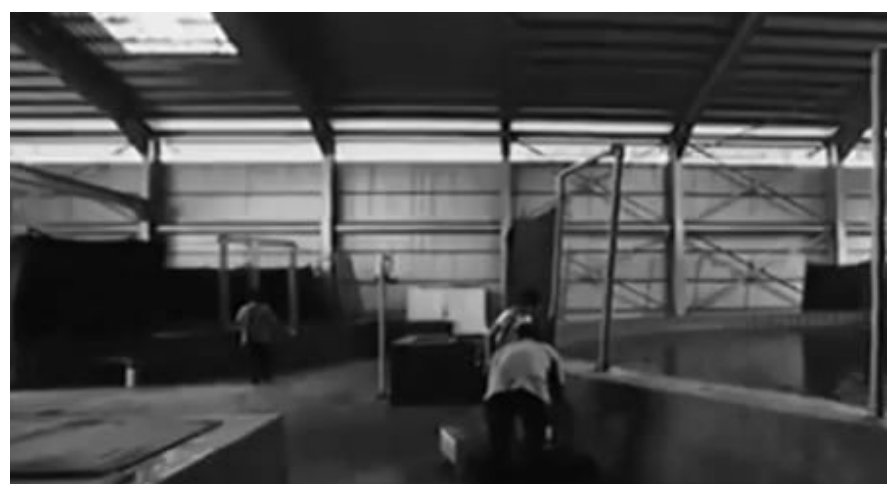

Gambar 1. Fasilitas budidaya ikan tuna sirip kuning merupakan salah satu fungsi bangunan yang dapat diterapkan kedalam desain akuarium untuk membantu mengurangi dampak menurunnya populasi ikan tuna sirip kuning. (Sumber: 1000 Meter, MetroTV)

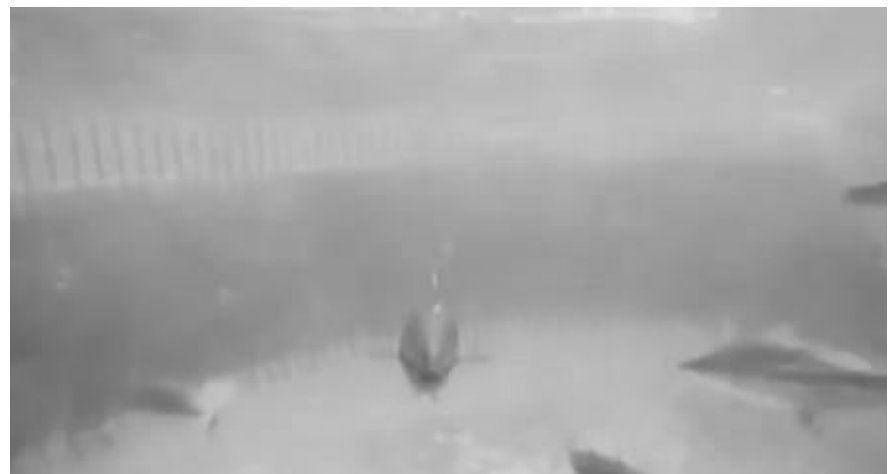

Gambar 2. Kolam pembesaran ikan tuna sirip kuning yang merupakan bagian dari fasilitas budidaya ikan tuna.

(Sumber: 1000 Meter, MetroTV)

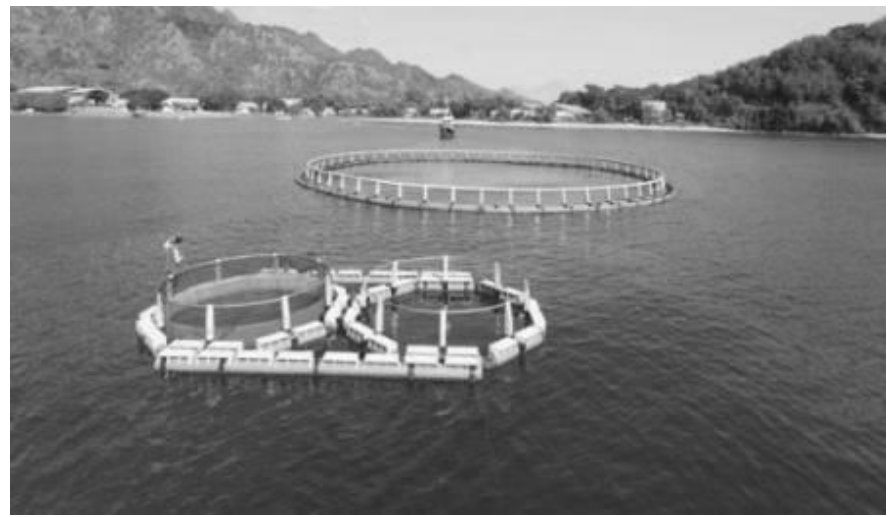

Gambar 3. Keramba pembenihan ikan tuna sirip kuning yang berada di lepas pantai untuk memenuhi kebutuhan ruang ikan tuna sirip kuning yang merupakan perenang cepat.

(Sumber: 1000 Meter, MetroTV) 
Ketahanan pangan Indonesia sebagai negara maritim sangat ditentukan oleh sumber daya lautnya. Oleh karena itu fenomena eksploitasi terhadap sumber daya laut perlu ditangani dengan lebih lanjut. Belum lagi fenomena penangkapan ikan yang berlebihan di Indonesia cenderung mengarah pada beberapa jenis yang memiliki permintaan tinggi sehingga terjadi eksploitasi masif pada jenis-jenis ikan tersebut.

Berdasarkan isu yang telah dipaparkan diatas maka simulasi desain akan mengarah pada fasilitas yang mampu mewadahi konservasi dan edukasi mengenai ekosistem laut berupa akuarium publik. Akuarium ini akan menampung berbagai jenis ikan air laut serta biota laut lainnya seperti ikan duyung, penyu, maupun terumbu karang. Dalam akuarium ini diharapkan tidak hanya menyediakan edukasi berupa informasi umum seputar biota laut (seperti nama spesies, ukuran, tempat tinggal, dst) tetapi juga edukasi yang bersifat khusus yakni pelestarian serta budidaya terhadap ikan yang terancam akibat penangkapan berlebih yaitu ikan tuna.

Lokasi yang digunakan dalam simulasi desain berada di Kecamatan Gerokgak, Kabupaten Buleleng, Bali. Lokasi ini dipilih karena memiliki perairan dengan pencemaran yang kecil serta keberadaan BBPPBL (Balai Besar Penelitian dan Pengembangan Budidaya Laut). BBPPBL yang berdiri sejak 1985 telah melakukan penelitian tentang budidaya ikan tuna sirip kuning.

Lokasi lahan berada pada daerah pesisir pantai di Jalan Singaraja-Gilimanuk, Buleleng, Bali. Akuarium Publik merupakan sebuah fasilitas konservasi dan wisata edukasi yang menampung berbagai jenis ikan yang dirasa memiliki potensi untuk dikembangbiakkan serta jenis ikan yang dalam kondisi kritis. Lahan berada di bibir pantai untuk memudahkan pasokan air laut serta pengembangbiakan ikan yang telah tumbuh dewasa dapat dilakukan langsung di laut. Kawasan ini terletak cukup jauh dari keramaian $( \pm 48 \mathrm{~km}$ dari Singaraja, Ibukota Kabupaten Buleleng), namun kawasan ini memiliki potensi pariwisata yang baik karena keindahan alamnya. Selain itu, kawasan ini juga berada dekat dengan tempat wisata religi, yaitu pura pulaki dan pabean serta kawasan wisata pantai pemuteran. Kedua lokasi wisata ini menambah kemungkinan wisata yang mungkin muncul pada lahan ini.

Lahan berada tepat di sebelah Balai Besar Penelitian dan Pengembangan Budidaya Laut Gondol (BBPPBL) yang dapat menjadi media pendukung sarana edukasi budidaya ikan tuna. Dengan adanya keramba lepas pantai yang telah disediakan oleh BBPPBL diharapkan nantinya dapat bekerja sama dalam membawa pengunjung ke tengah laut untuk melihat proses pengembangbiakan ikan tuna sirip kuning. Hal ini dapat menjadi keuntung bagi desain akuarium dalam memberikan edukasi bagi masyarakat mengenai budidaya ikan tuna yang jarang diketahui oleh masyarakat. Dengan ini diharapkan mampu mengajak pengusaha dalam bidang perikanan untuk ikut serta dalam budidaya ikan tuna sirip kuning yang mulai terancam punah.

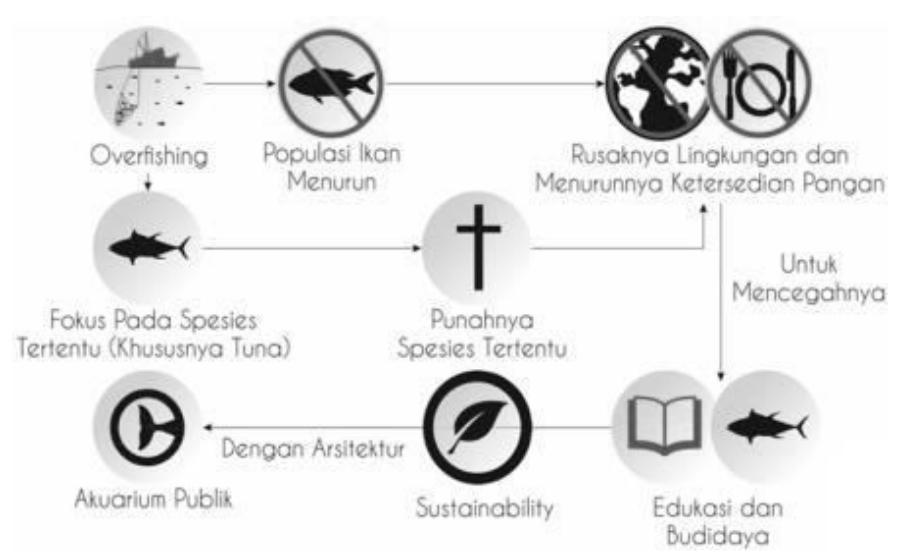

Gambar 4. Isu dan Solusi Arsitektur yang dapat ditawarkan untuk mencapai fasilitas edukasi yang menaungi proses budidaya.

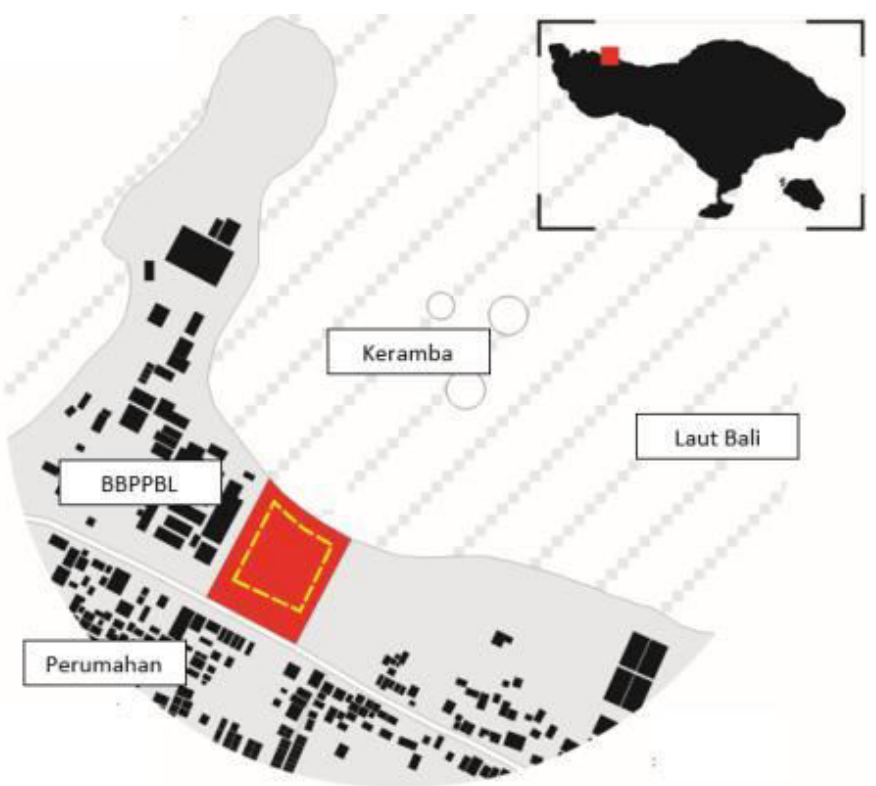

Gambar 5. Lokasi lahan berada dipinggir pantai untuk memudahkan pasokan air laut serta proses budidaya indukan ikan tuna sirip kuning yang memerlukan kedalaman air $10-15 \mathrm{~m}$.

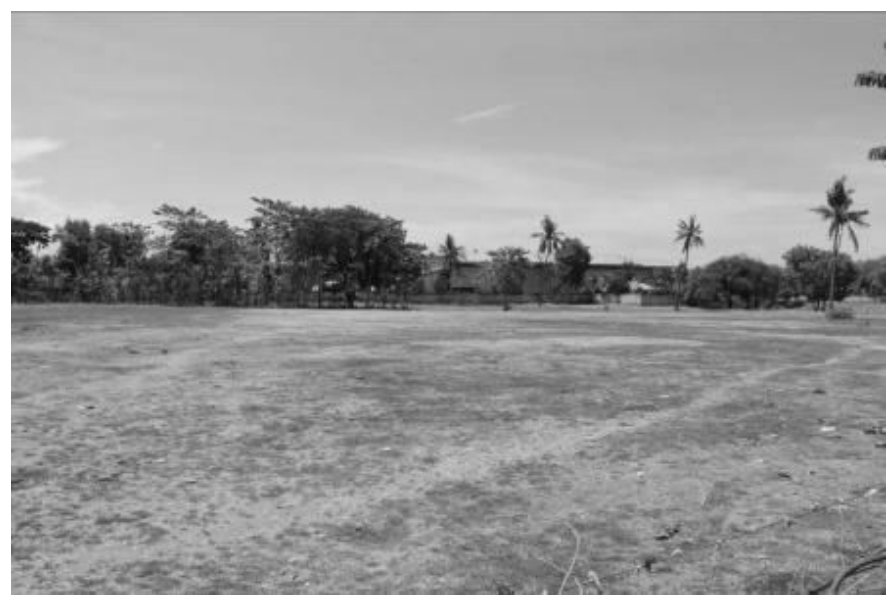

Gambar 6. Kondisi lahan yang merupakan lahan kosong yang berada di pesisir pantai bali utara tepatnya pada Jalan Singaraja-Gilimanuk, Kabupaten Buleleng, Bali.

(Sumber: dokumentasi pribadi) 


\section{METODA PERANCANGAN}

Untuk menciptakan sebuah desain yang mampu mewadahi regenerasi lingkungan dan mengedukasi masyarakat tentang pentingnya kelestarian lingkungan dapat menggunakan Biophilic Design sebagai landasan dalam merancang. Fasilitas budidaya nantinya diharapkan dapat mengedukasi dan dapat membuat masyarakat cinta terhadap lingkungannya.

Metode yang digunakan penulis dalam merancang objek akuarium ini adalah Biomorphic Form \& Patterns yang merupakan bagian dari Biophilic Design. Penggunaan Biomorphic Form \& Patterns bertujuan agar pengunjung memiliki rasa keterikatan dengan objek rancang akuarium ini. Hal ini dilakukan dengan membuat bentuk dasar bangunan yang mudah dikenal dengan membuat sedikit perubahan pada bentuk akhirnya.

Biomorphic Forms \& Patterns digunakan untuk memberikan elemen desain yang representatif bagi pengguna untuk berhubungan langsung dengan lingkungannya. Tujuan utama Biomorphic Forms \& Patterns adalah membentuk lingkungan yang menarik secara visual untuk meningkatkan kemampuan kognitif serta membantu mengurangi stress pengunjung. Sebuah ruang yang menerapkan Biomorphic Forms \& Patterns akan terasa menarik, nyaman, dan kontemplatif [3].

Dalam buku 14 Pattern of Biophilic Design oleh William Browning penerapan Biomorphic Forms \& Patterns dapat dilakukan melalui elemen desain yang bersifat dekoratif dan bentuk dasar bangunan maupun dalam fungsinya. Keduannya dapat diterapkan bersamaan untuk meningkatkan pengalaman biophilic. Adapun kualitas Biomorphic yang ingin dicapai pada objek rancang akuarium ini adalah sebagai berikut :

1) Bentuk dasar bangunan memiliki keterikatan terhadap fungsinya sebagai akuarium

2) Sirkulasi dalam akuarium merupakan sirkulasi searah yang dibentuk berdasarkan pola pergerakan ikan

3) Ornamen pada fasad bangunan memberikan indikasi terkait lingkungan sekitarnya

Dalam penerapannya pada objek desain akuarium bentuk dasar massa pertama akuarium diambil dari kepala, sirip, dan ekor dari ikan tuna. Kepala digunakan sebagai bentuk dasar lobby. Sirip digunakan sebagai tampak samping yang mana bagian depan sirip yang tinggi menunjukkan keberadaan lantai tertinggi dari massa pertama. Sedangkan ekor dari ikan tuna digunakan sebagai denah bangunan. Massa kedua terbentuk dari telur ikan yang melambangkan generasi berikutnya melalui budidaya.

Dalam membentuk sekuen diterapkan juga Biomorphic Forms \& Patterns. Sekuen akan dibentuk berdasarkan pergerakan ekor ikan yaitu kiri-kanan. Pola ini dapat memunculkan sekuen yang menyembunyikan kondisi area selanjutnya. Sekuen yang ada memunculkan beberapa area akuarium. Area - area ini terlihat tersembunyi satu sama lainnya akibat sekuen yang dibentuk berkelok-kelok. Dengan demikian akan menimbulkan pengalaman yang berbeda bagi pengunjung.

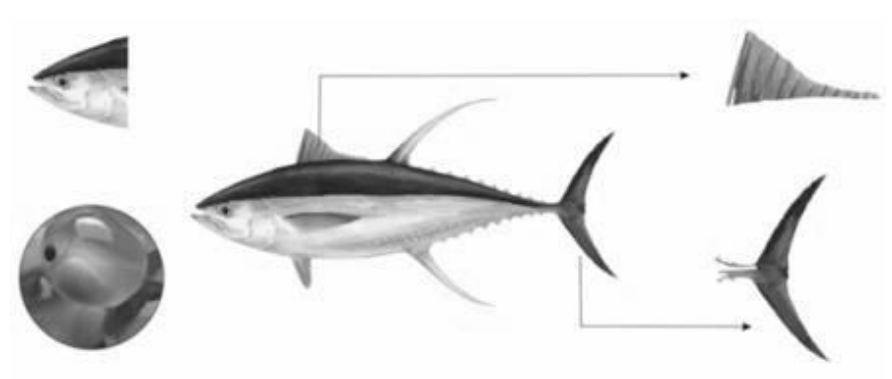

Gambar 7. Bentuk dasar bangunan diambil dari bentuk ikan tuna. Bentuk kepala ikan akan menjadi fasad dari lobby, sirip ikan melambangkan jumlah lantai yang semakin kedepan semakin tinggi, dan ekor ikan menjadi bentuk dasar dari denah bangunan, sedangkan bentuk telur ikan menjadi massa kedua yang menaungi fasilitas edukasi budidaya sebagai lambang hadirnya generasi baru.
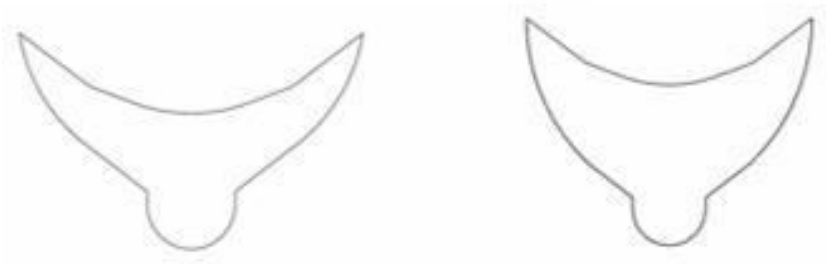

Bentuk dimulai dari ekor ikan tuna yang kemudian ditarik bagian belakangnya sehingga berbentuk sedikit gemuk
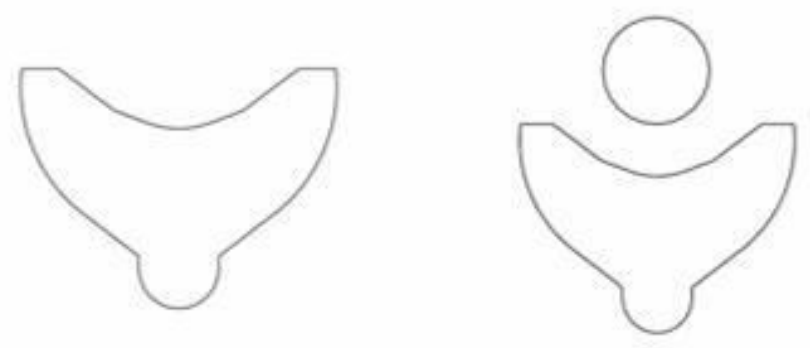

Bagian runcing pada ekor tersebut dipotong, lalu ditambahkan massa kedua yang berbentuk bulat pada bagian utara
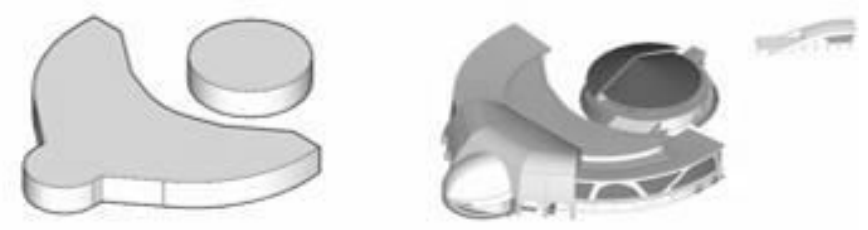

Kedua massa ditarik keatas untuk meciptakan lantai pada bangunan, kemudian ditambahkan elemen arsitekturalnya

Gambar 8. Perubahan bentuk bangunan berdasarkan bentuk dasar ikan tuna.

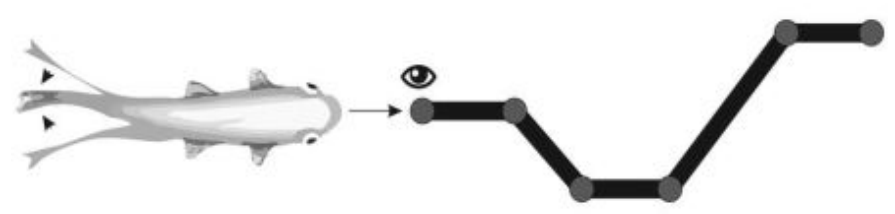

Gambar 9. Sekuen dibentuk berdasarkan pola pergerakan ekor ikan yang bergerak kekiri-kanan. Didalam akuarium pengunjung dibawa pada area berbeda melalui sirkulasi satu arah yang berkelok-kelok 


\section{HASIL DAN EKSPLORASI}

Akuarium publik merupakan fasilitas publik yang bersifat edukatif dengan memberikan informasi mengenai biota air. Pada umumnya akuarium publik menaungi berbagai jenis hewan dan tanaman air yang kemudian ditunjukkan kepada pengunjung. Untuk menambah ketertarikan pengunjung pada objek rancangan maka bentuk dari akuarium dibuat menyerupai bagian-bagian dari ikan tuna (gambar 7 dan 8). Selain itu bentuk elemen-elemen desain dibuat menyerupai pola yang ada di alam, seperti kaca yang dibuat dengan bentuk sisik ikan dan keberadaan greenwall pada sisi luar akuarium. (gambar 13)

Didalam akuarium dibuat sekuen untuk menambahkan elemen kejutan pada pengunjung. Sekuen dibuat dengan menyuguhkan area dengan ikan dalam jumlah banyak pada bagian awal massa I. Kemudian pada bagian akhir massa I pengunjung akan dibawa ke area dengan ikan dengan jumlah sedikit dan terancam punah akibat penangkapan berlebih. Disini diharapkan pengunjung ikut terbawa suasana sepi dan merenungkan kondisi ikan laut yang ada saat ini. Setelah itu pengunjung dibawa ke massa II yang menaungi edukasi budidaya ikan sebagai pemecahan masalah terancamnya spesies ikan tertentu.
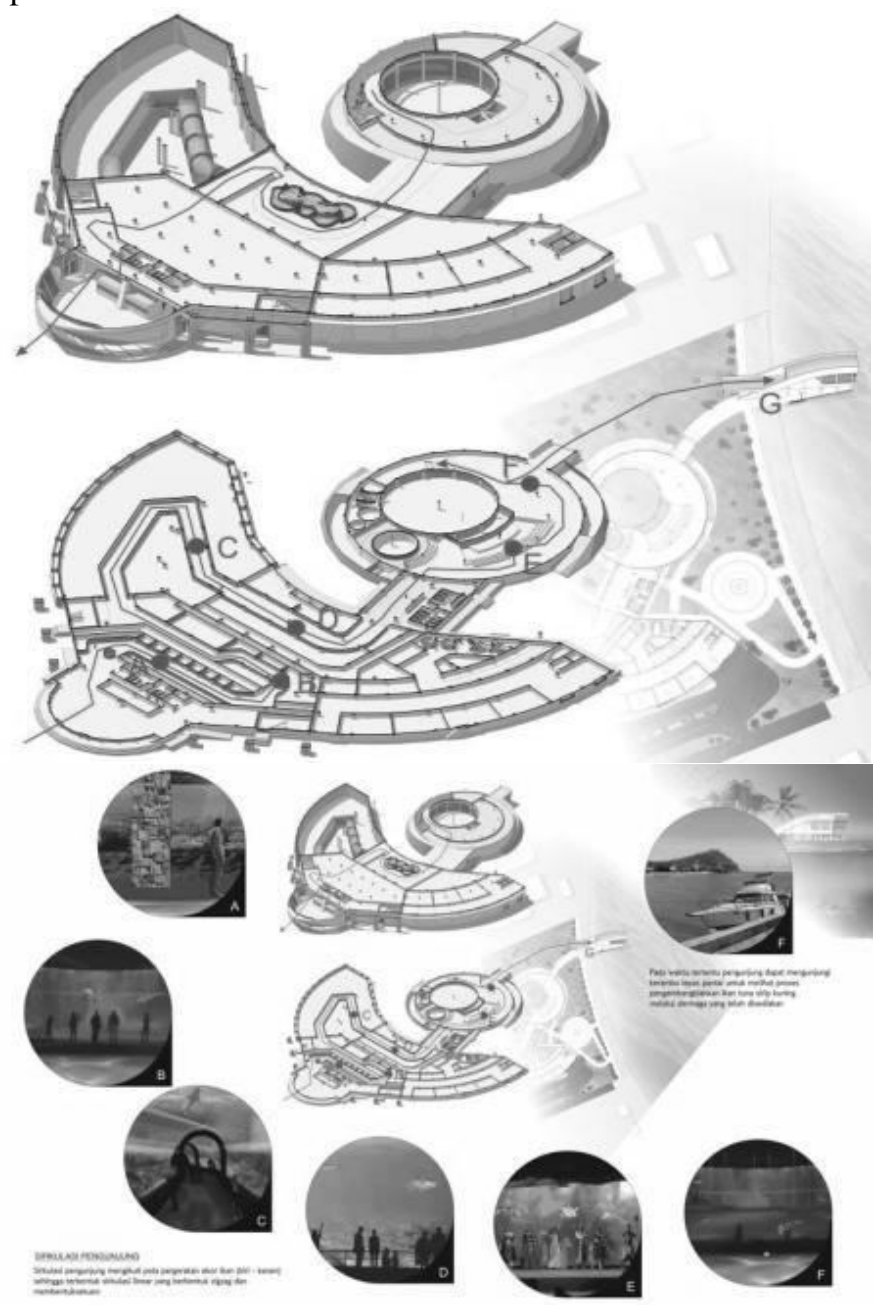

Gambar 10. Sirkulasi pengunjung.

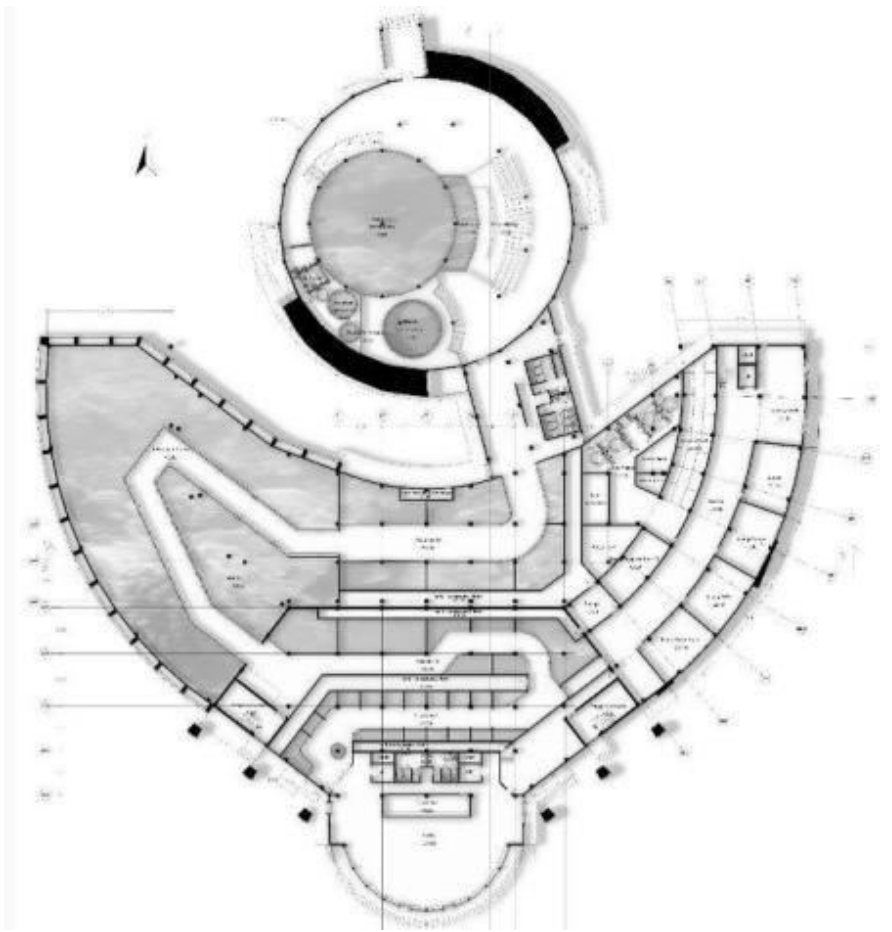

Gambar 11. Denah lantai 1 banngunan yang mengambil bentuk dasar ekor ikan tuna pada massa I (bawah) dan telur ikan pada massa II (atas).

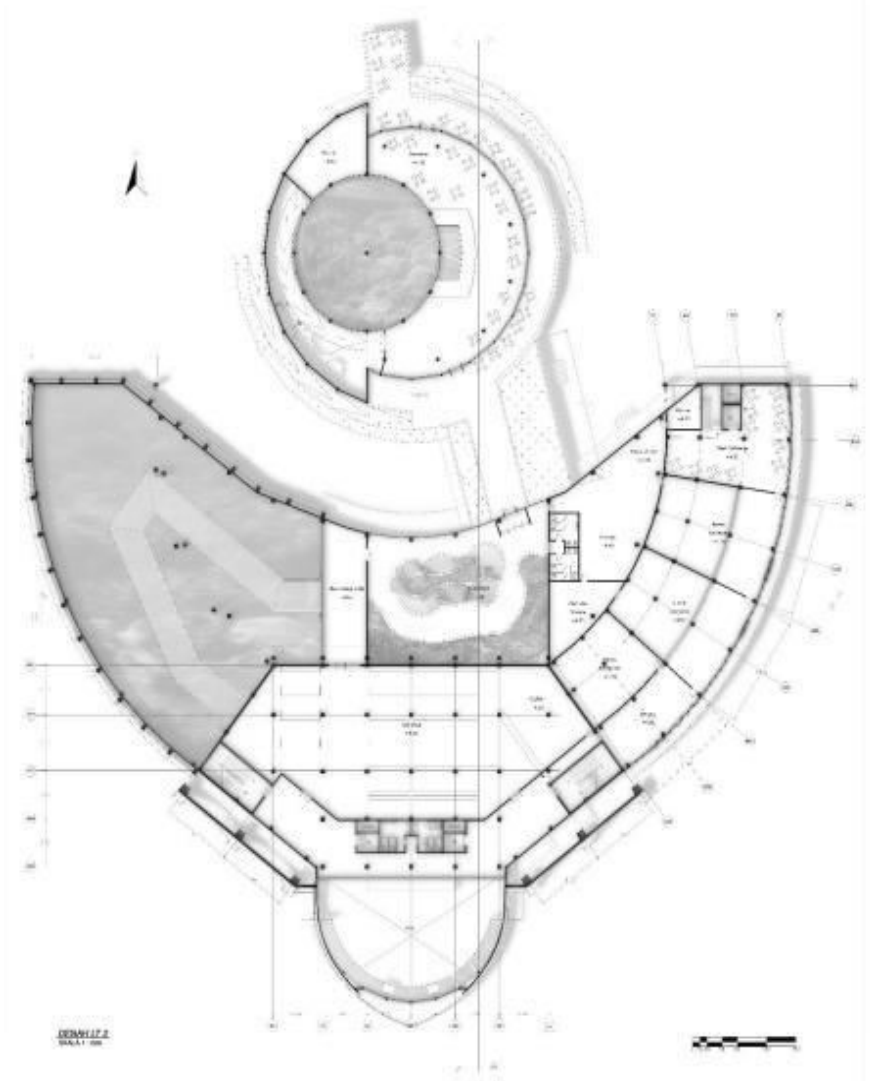

Gambar 12. Denah lantai 2 banngunan yang mengambil bentuk dasar ekor ikan tuna pada massa I (bawah) dan telur ikan pada massa II (atas). 
Bagian interior bangunan memiliki gallery akuarium yang berbeda-beda yang disesuaikan dengan ukuran dan status konservasinya di alam. Pada massa I dibagi menjadi empat area berbeda yakni A,B,C,dan D. Area A berisi gallery ikan berukuran kecil-sedang yang konfigurasi tiap akuariumnya terkesan acak namun tetap memiliki suatu keteraturan. Area B berisi gallery ikan berukuran sedang-besar. Area $\mathrm{C}$ merupakan akuarium raksasa yang menampung berbagai jenis ikan dan terumbu karang dari ukuran kecil hingga besar, dalam area ini biota laut dipilih berdasarkan kecocokan suhu dan tingkat keasaman air sehingga menciptakan kenyamanan bagi ikan didalamnya. Pada area ini pengunjung akan dibawa ke suatu terowongan yang memberikan pengalaman bawah laut. Area D merupakan akuarium besar yang berisi berbagai hewan langka. Ukuran akuarium yang besar dimaksudkan untuk memberi efek kejutan berupa adanya akuarium yang besar namun memiliki sedikit biota laut didalamnya. Hal ini bertujuan agar pengunjung sadar bahwa di laut lepas sekarang ini beberapa jenis hewan laut telah terancam punah.

Pada massa II berlangsung pertunjukkan drama pada area E dan kegiatan edukasi budidaya tuna untuk dibesarkan. Disini pengujung diajak ke sebuah ruang untuk mempelajari teori dan kemudian melihat langsung pembenihan ikan tuna pada kolamkolam yang telah disediakan. Kolam didesain tidak memiliki sudut agar tuna dapat bergerak dengan bebas.

Setelah melihat proses pembenihan ikan tuna, maka pengunjung diajak untuk melihat tuna yang telah dewasa ke keramba lepas pantai melalui kapal pada sebuah dermaga dengan memanfaatkan lokasi yang berada dekat dengan penelitian budidaya ikan tuna sirip kuning yang telah memiliki keramba lepas pantai.

Kemudian pengunjung kembali kedalam bangunan dan menuju lantai dua pada massa II yang merupakan caffetaria. Disini pengunjung dapat menikmati hasil budidaya yang telah berlangsung dalam bangunan ini. Setelah itu pengujung menuju lantai dua pada massa I yang menaungi fasilitas interaksi dengan biota laut (touchpool) dan juga area observasi kearah akuarium area $\mathrm{C}$ yang merupakan akuarium raksasa dari atas. Di lantai dua ini juga tersedia gift shop sebagai tempat oleh-oleh bagi pengunjung. Dari area gift shop pengunjung dapat kembali ke lantai satu untuk menuju lobby dan keluar bangunan.

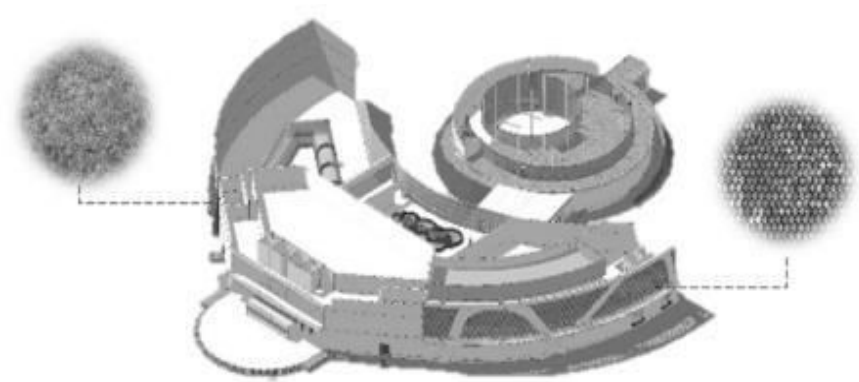

Gambar 13. Fasad bangunan yang mengambil elemen alam seperti penerapan greenwall dan kaca yang berbentuk sisik ikan.

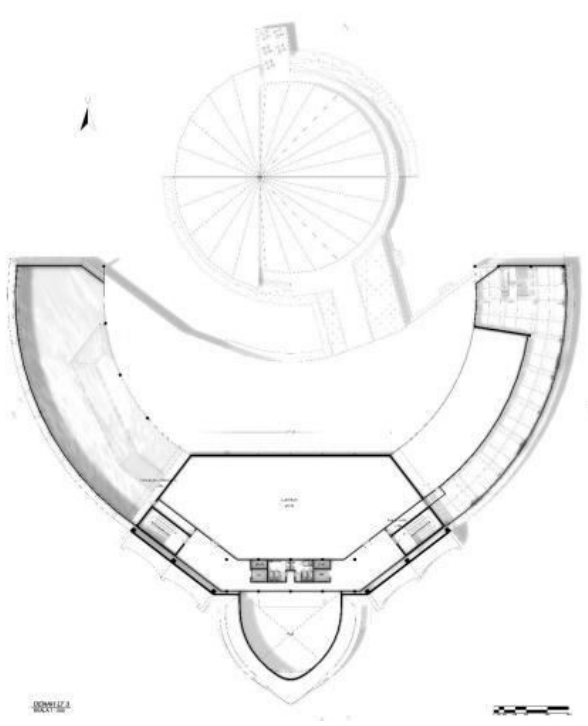

Gambar 14. Denah lantai 3.

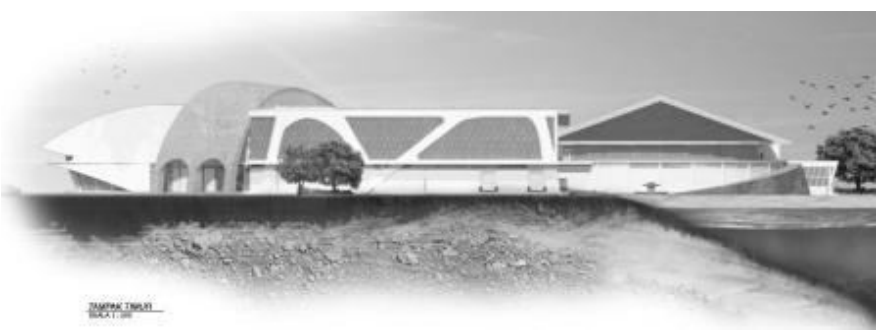

Gambar 15. Tampak timur yang memperlihatkan bentuk mulut ikan (kiri).

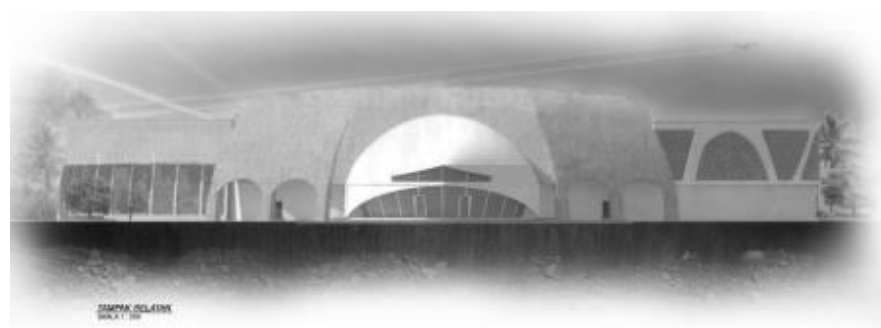

Gambar 16. Tampak selatan yang memperlihatkan bentuk mulut ikan

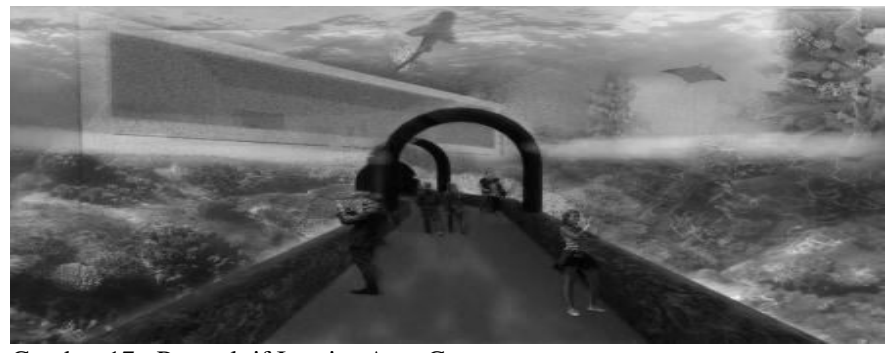

Gambar 17. Perspektif Interior Area C.

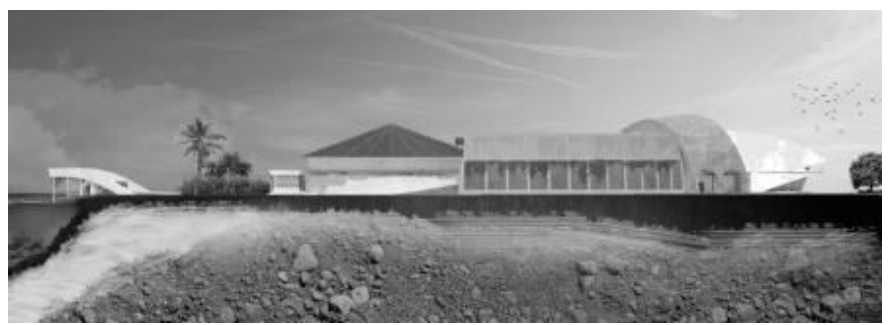

Gambar 18. Tampak barat. 


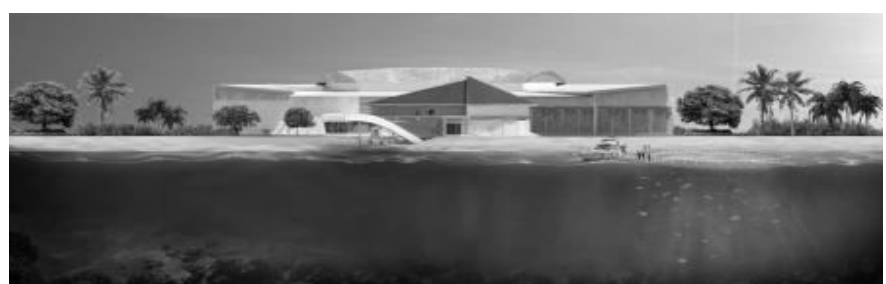

Gambar 19. Tampak utara.

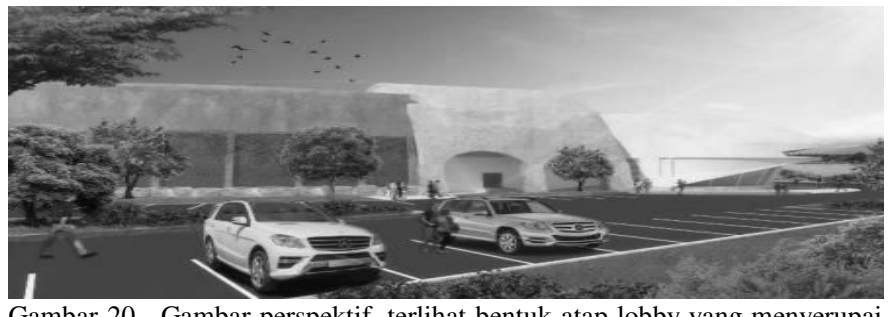

Gambar perspektif, terlihat bentuk atap lobby yang menyerupai kepala ikan yang merupakan tempat masuk kedalam bangunan.

\section{KESIMPULAN}

Akuarium publik merupakan salah satu usaha konservasi biota laut. Selain konservasi fasilitas ini juga dapat mengedukasi masyarakat tentang berbagai spesies biota laut. Masyarakat dapat mengetahui dan merasa semakin dekat dengan lingkungannya. Namun hal ini masih dirasa kurang untuk menjaga stabilitas populasi ikan konsumsi seperti tuna sirip kuning. Untuk itu diperlukannya usaha budidaya bukan hanya oleh pemerintah tetapi juga masyarakat.

Melalui artikel ini edukasi budidaya ikan tuna sirip kuning juga berada dalam suatu akuarium publik. Sehingga pengunjung tidak hanya dapat merasakan pengalaman melihat koleksi hewan, tetapi juga dapat ikut serta dalam mempelajari cara budidaya ikan tuna yang jarang diketahui. Metode Biomorphic Form \& Patterns digunakan untuk mendapatkan keterikatan antara lingkungan, bangunan, dan pengunjung. Sehingga bentuk dari akuarium dibuat menyerupai bagianbagian dari ikan tuna. Bentuk-bentuk ini memunculkan rasa keterikatan pengunjung dengan objek rancang serta membentuk pola sirkulasi yang unik.

\section{DAFTAR PUSTAKA}

[1] WWF, "Decreasing Fish Stocks," 2008.

[2] J. A. Hutchings and J. D. Reynolds, "Marine Fish Population Collapse: Consequences for Recovery and Extinction Risk," Bioscience, vol. 54, no. 2, pp. 297-309, 2004.

[3] W. D. Browning, C. O. Ryan, and J. O. Clancy, 14 Patterns Of Biophilic Design: Improving Health \& Well-Being In The Built Environment. New York: Terrapin Bright Green, LLC, 2014. 